\title{
ASPECTS OF PREACHING AND MINISTRY IN EAST AND WEST AD 400-600
}

\section{The Liturgical Context}

There is evidence of both eucharistic and non-eucharistic liturgies in the period I am dealing with, and as well as taking place in a church or martyr-shrine these liturgies were conducted in monasteries and convents, at cemeteries, in the open air, and in the context of processions. ${ }^{1}$ Most liturgies comprised readings from both the Old and New Testaments, some aspect of which the homilist then usually focused on in the course of his preaching, to which the congregation was invited to listen by an announcement from the deacon. The main preacher was the bishop, although there was some local variation in this, and while in special circumstances he could delegate this responsibility to a priest or a deacon, it was the bishop who appeared in the legal codes as the one responsible for continual preaching and teaching. ${ }^{2}$ This legal obligation on the bishop/preacher is reflected particularly in the very frequent comments in homilies calling on his audience to pay attention, ${ }^{3}$ and to the effect that he owes them a debt, which of course is the homily itself. The fact that the doors were closed meant that the preacher could ensure that he paid his debt to his congregation. Gregory Nazianzen (c. 330-390) informs us that topics such as

(1) In general on the topic of preaching in this period see J. BingHAM, Origines Ecclesiasticae; or the Antiquities of the Christian Church, London, 1834, Book XIV, ch. IV, pp. 516-617 (still a mine of information); A. Olivar, La predicación cristiana antigua (Biblioteca Herder Sección de teología y filosofía, 189), Barcelona, 1991; Preacher and Audience. Studies in Early Christian and Byzantine Homiletics, ed. by M. B. Cunningham and P. Allen (A New History of the Sermon, 1), Leiden, Boston, and Cologne, 1998.

(2) See e.g. Codex Theodosianus 16.2.38; Codex Theodosianus, ed. by P. Krueger and T. Mommsen, vol. 1/2, Hildesheim, 1990, p. 848.

(3) See in detail Olivar, La predicación, pp. 815-833. 
the following were commonly treated in preaching: the creation of the world, the human soul, angels both good and bad, divine providence, the creation of the human race and its restoration through Christ, the two covenants, the first and second coming of Christ, his incarnation and passion, the general resurrection, the day of judgment, and above all (perhaps surprisingly) the difficult topic of the doctrine of the Trinity. ${ }^{4}$ In some places the bishop preached every day, especially during Lent and Easter, and sometimes twice a day, in the morning and again in the evening. During the Easter vigil and on certain other feasts it was possible for a series of preachers to speak, a practice that must have affected the length of such homilies.

The authority of the bishop and the importance of his teaching role when preaching is illustrated by the fact that generally he sat on an elevated chair in the middle of the nave of the church while the congregation remained standing around him. This practice derived from Judaism, as we can see from such passages as John's Gospel 8:2: “He sat down and taught the people in the temple". On the other hand, we know that in some churches sitting was allowed for both preacher and audience, whereas when the priest or presbyter preached he was required to remain standing. We are informed that in Gaul the disabled or infirm were allowed to sit when the passions of the martyrs were read, when there were long readings, or when the homily was delivered. ${ }^{5}$ There are frequent references in the homilies to crowding and fatigue among the audience if the homily was long. ${ }^{6}$ The usual arrangement during a liturgy whereby the homilist sat and the congregation remained standing around him resulted in a physical immediacy that communicated itself in the contents of the homily and in audience reactions. ${ }^{7}$

\section{The Art of Preaching}

The homily was not only the main teaching medium of the early church but was intrinsic to the cultural and political self-identity of Christians.

(4) Greg. Naz., Oratio 22.35-36; ed. by J. Bernardi (SC, 247), Paris, 1978, pp. 134.5-136.1.

(5) On the stance of preachers and audiences see the discussion in BINGHAM, The Antiquities of the Christian Church, Book XIV, ch. IV. XXIV-XXV, pp. 590-596.

(6) See Olivar, La predicación, pp. 670-721, on the length of homilies.

(7) See Cunningham and Allen, Preacher and Audience, passim. 
It was thus largely responsible for the scriptural and moral education of the congregation and for the transmission of social, cultural, and religious norms. ${ }^{8}$ Homilies from the early church survive in their thousands, and many more thousands must also be lost. It was common for the preacher to begin by taking some aspect of the reading of the day and to exegete it, often combining it with reference to the Psalm which the audience had just sung. On the basis of his exegesis the preacher then often drew lessons for everyday life, a part of the homily known as the ethikon. The contents of this section could be varied, ranging from warnings about attending horse-racing, games, or the theatre, to denunciations of ostentation, greed, and grave-looting, and exhortations to fasting, almsgiving, chastity, frequent church-going, and reading the Scriptures at home. In general the homily closed with a doxology, along the lines of: "May we all gain the benefits of heaven, by the grace and loving kindness of our Lord Jesus Christ, with whom to the Father together with the Holy Spirit be glory, power, honour, now and always, and forever and ever. Amen." ${ }^{9}$

Many preachers prepared their homilies beforehand, which was not always a recipe for success. Augustine relates that he had appointed a reader to read a certain Psalm on which he himself intended to preach. The reader, however, became nervous and read the wrong Psalm, on which Augustine was then obliged to deliver an extemporizing homily. ${ }^{10}$ Other preachers did not prepare their text. ${ }^{11}$ Gregory of Tours (c. 538-594), in his History of the Franks, relates that Sidonius Apollinaris, the bishop of Clermont-Ferrand (b. 531, d. after 587), was known for his ability to preach brilliantly without preparation. On one occasion, when Sidonius was invited to the dedication of a monastery church as the liturgical celebrant and consequently as the preacher, someone hid the missal containing the liturgical order of the day and Sidonius was forced to improvise not only the homily but also the en-

(8) See P. Allen and W. Mayer, "Computer and Homily: Accessing the Everyday Life of Early Christians," VC, 47 (1993), pp. 260-280, esp. 260-261.

(9) Template reconstructed on the basis of John Chrysostom's homilies by G. BADY, "La Tradition des œuvres de Jean Chrysostome, entre transmission et transformation," RÉB, 68 (2010), pp. 149-163, at 155.

(10) En. in Ps. 138.1; Nuova Biblioteca Agostiniana (NBA) 28/1 (1993), p. 458; trans. by M. Boulding, Works of Saint Augustine (WSA) 3/20, Hyde Park, NY, 2004, p. 256.

(11) On extemporizing vs. prepared preaching see Olivar, La predicación, pp. 589-633. 
tire liturgy. We are told he did this with such skill that those present thought they had listened not to a man but to an angel. ${ }^{12}$ Unfortunately we have not a single surviving homily from Sidonius. Gregory I, bishop of Rome (590-604), admits that he often found the difficult passages of Scripture, particularly Ezekiel, which he could not understand in his private study, could be grasped more readily when he was preaching in public without preparation ${ }^{13}$ - in other words, improvisation was the work of the Spirit.

Here, in examining the art of preaching, I shall focus on two preachers who are perhaps the most famous, or in terms of their surviving homilies the most prolific, in Christian antiquity - John Chrysostom and Augustine.

First, John. The topics that occupy John (d. 407) and the scriptural examples that he adduces tend to fall into familiar patterns. Wealth, pride, and power and their negative consequences are issues frequently addressed by him. In association with these topics he is anxious to promote the virtues of humility and charity, but at the same time the correct behaviour and belief of his congregation are of primary concern to him. On other occasions, even when the rhetorical exaggeration is taken into account, he is simply filled with pleasure at the responsiveness of the audience. The Old and New Testament examples of Job, the three boys in the furnace, the tax-collector and the Pharisee, and the widow who gave everything she had are firm favourites and appear frequently throughout his homilies. The ministry, life, and character of the apostle Paul are much admired by John and likewise receive frequent emphasis. ${ }^{14}$ As a preacher John puts at the disposal of his congregation his wide command of Scripture, developed during his ascetical life. In fact, educating them in the Scriptures is one of his priorities in his preaching, so when they supposedly say that they cannot understand scriptural passages, he reacts:

Are they [the Scriptures] spoken in Hebrew, or Latin, or any other foreign language? Aren't they spoken in Greek, to you who understand the Greek language? 'Yes, but they are expressed obscurely'...

(12) Greg. Tur., Hist. franc. 2.22; 2nd ed., ed. by B. KRusch, MGH Scr. Merov. 1/1, Hanover, 1937, p. 67. 24-29.

(13) Greg. Mag., Hom. 2 in 2 Hiezech.; ed. by M. Adriaen (CCSL, 142), Turnhout, 1971, p. 225.4-6.

(14) See W. Mayer and P. Allen, John Chrysostom (ECF), London and New York, 2000, p. 29. 
There are a thousand stories in the Bible: tell me one of them. But you can't tell one of these... 'Oh but', they say, 'we have the same things read to us every day from Scripture'. And don't you hear the same things every day in the theatre? Don't you see the same sight at the horse-races? Aren't all things the same? Doesn't the same sun rise every morning? Don't you eat the same foodstuffs every day? I would ask you, seeing you say that you hear the same things every day, what part of the prophets, what apostle, what epistle, was read? But you can't tell: you seem to be hearing strange topics. ${ }^{15}$

John favoured a direct preaching style, with many examples from everyday life to entertain and edify his congregation. His directness can result in sharp messages, such as the one contained in the following ethicon:

[God] made your feet, not so that you'd run towards evil but towards good. He made your stomach, not so that you'd make it burst but so that you might exercise wisdom. He ordained a desire for procreation, but not for fornication and adultery. He gave you a mind, not so that you'd blaspheme, not so that you'd revile him, but so that you'd be without guile. He also gave us money, so that we'd use it according to our need. And he gave us strength, so that we'd be users of it according to our need. He made the arts, so that our life would be sustained, not so that we'd detach ourselves from spiritual matters or pay attention to sordid arts, but to necessary ones, so that we'd serve others, not plot against each other. He gave us a roof to keep off the rain - and that's it -, not so that it would be decorated with gold, while the poor person is perishing from hunger. ${ }^{16}$

The last antithesis in this passage - between rich and poor, wealth and poverty - can be found throughout Chrysostom's preaching, ${ }^{17}$ but next I want to examine these themes in Augustine of Hippo.

The most important part of Augustine's caritative programme was almsgiving, a phenomenon which besides its practical aspect had also psychological, social, and eschatological dimensions for him. In his preaching he used almsgiving as a way of building community and solidarity in his congregations in the face of the challenges presented

(15) John Chrys., Hom. 3 in 2 Thess. (CPG 4435); PG 62, 485.11-486.5.

(16) Hom. 11 in ep. ad Phil. (CPG 4432); PG 62, 262.5-19. Trans. in P. ALLEN, John Chrysostom: Homilies on Paul's Letter to the Philippians, Writings from the Greco-Roman World, Atlanta, forthcoming.

(17) See further MAyer, in Preaching Poverty, pp. 69-111. 
by the Donatist church in North Africa, a context in which, following the Pauline model, unity was more important than the act of charitable giving. ${ }^{18}$ He explains this to his congregation as follows:

I don't know how it is, my brothers and sisters, but the spirit of the person who actually hands something to a poor man experiences a kind of sympathy with common humanity and infirmity, when the hand of the one who has, is actually placed in the hand of the one who is in need. Although the one is giving, the other receiving, the one being attended to and the one attending are being joined in a real relationship. ${ }^{19}$

Yet in order to be truly efficacious, he advises, almsgiving involves fasting, prayer, forgiveness, and above all a psychological or dispositional transformation on the part of the donors, whereby they are to look after their own sick souls first. ${ }^{20}$ Proper attention to humility by the givers and respect for the common humanity which exists between donor and recipient are also emphasised - while the rich are not necessarily proud, the poor are not ipso facto humble either, and cannot count on being saved simply because of their poverty:

Someone may have plenty of money and resources, and yet not be haughty about it, and then he or she is poor. Another may have nothing, yet be covetous and puffed up, and then God classes him or her with the rich and reprobate. God questions both rich and poor in their hearts, not in their treasure-chests or their houses. ${ }^{21}$

This leads to an eschatological spiritualizing of poverty which pervades Augustine's discourse on the topic. Among the strategies he uses to exhort the various congregations to give alms are the depiction of the poor as porters who carry wealth from one world to the next:

Suppose you gave it [alms] to the poor as porters. You know, after all, your eyes will tell you that those you give alms to on earth can walk. Well, what you give them they carry to heaven, and you don't get back merely what you give. In exchange for the goods of

(18) Allen and Morgan, in Preaching Poverty, p. 163.

(19) Augustine, Sermo 295.5 (NBA 32/2), Rome, 1984, p. 840; trans. E. HiLL (WSA 3/7), New Rochelle, NY, 1995 p. 181. See Allen and Morgan, in Preaching Poverty, pp. 142-143.

(20) See Allen and Morgan, in Preaching Poverty, p. 132 with n. 90.

(21) En. in Ps. 48, Sermo 1.3 (NBA 25), Rome, 1967, p. 1196; trans. by BoulDING (WSA, 3/16), Hyde Park, NY, 2002, pp. 352-353. 
earth, you see, you are going to receive those of heaven, for mortal things immortal ones, for temporal things everlasting ones. ${ }^{22}$

Nowhere, however, are the givers asked to give more than they can - good intentions and no money should not be a cause for worry. ${ }^{23}$ On the question of voluntary poverty Augustine says that showy poverty is no guarantee of a godly life, and that there are people who are more willing to distribute all their possessions to the poor than to become God's poor themselves. ${ }^{24}$ That the voluntary poor are a small minority is clear, and he gives no orders for the masses to follow the example of total renunciation. On the contrary, as scholars have argued recently, Augustine opposed radical voluntary poverty as espoused by the aristocracy because it ran the risk of tearing apart the social fabric by disregarding slaves, tenants, and employees. ${ }^{25}$ Voluntary poverty in the context of the monastic community accommodated in Augustine's episcopal residence is, however, quite another matter: he warns the monastics that if he discovers any of them still owning property, they will be expelled from the monastery and the clergy. ${ }^{26}$

Up to now I have been speaking about the activity of preachers in the liturgical context, particularly some of the topics they focused on in the course of their preaching. However, it is clear that their ministry extended far beyond the walls of the church and the context of worship, and it is to this extended ministry that we now turn.

\section{Episcopal Epistolary Networks in the Service of Ministry}

Like homilies from Christian antiquity, the letters that our preachers and ministers wrote have perished in their thousands. ${ }^{27}$ However, from what remains we can still piece together some elements in their epis-

(22) Augustine, Sermo 107A.2 (NBA 30/2), Rome, 1983, p. 340; trans. by HiLl (WSA 3/4), Brooklyn, NY, 1992, p. 120.

(23) En. in Ps. 125.5 (NBA, 28/1), Rome, 1993, p. 116; trans. by Boulding (WSA 3/20), Hyde Park, NY, 2004, p. 73.

(24) En. in Ps. 71.3 (NBA 26), Rome, 1970, p. 790; trans. by Boulding (WSA 3/17), Hyde Park, NY, 2001, p. 454.

(25) Summed up in C. Lepelley, "Facing Wealth and Poverty: Defining Augustine's Social Doctrine," The Saint Augustine Lecture 2006, Augustinian Studies, 38 (2007), pp. 1-17 at 13-16, with lit.

(26) For details see Allen and Morgan, in Preaching Poverty, p. 147.

(27) On letter-writing in Christian antiquity see P. Allen, “How to Study Episcopal Letter-writing in Late Antiquity: An Overview of Published Work 
tolary networks that, to a greater or lesser degree, they put at the service of their communities. Firmus, bishop of Caesarea in Cappadocia (d. before 439) demonstrates a pastoral concern in his letters, but his ministry is directed principally to those like himself who were cultivated and upper-class. Many of his short letters are little more than greeting cards, sent to his networks to ensure continuing contacts that might prove useful. (We have only one surviving homily of his, preserved in an Ethiopic translation..$^{28}$ ) Firmus enjoyed banquets and hunting, as the gifts he sent or received with his letters prove. ${ }^{29}$ On one occasion, accompanying a letter from another bishop, he received four partridges, two young horses, half a large ham, and a flask of wine, and, at a later stage, the loan of a hunting dog from a friend..$^{30}$ On another occasion Firmus received as a gift a large fish from the Euphrates, of the species that can weigh up to approximately $150 \mathrm{ki}$ los. The delicacy was served at a banquet, he tells us, and the leftovers distributed to the poor. ${ }^{31}$ Such gifts supported the epistolary networks that bishops needed both socially and pastorally. ${ }^{32}$

While there is evidence of preachers and ministers traveling to visit their flocks, sometimes, as in the far-flung regions of Egypt, this was not practicable. From at least the third century onwards, the patriarchs of Alexandria adopted the pastoral measure of sending an official letter once a year to the entire country, announcing the dates of the forthcoming periods of Lent, Easter, and Pentecost, and commenting on current social or religious abuses..$^{33}$ These festal letters, as they are

on the Fifth and Sixth Centuries," Scr, 6 (2010), pp. 130-142, with literature on earlier centuries.

(28) CPG 6121.

(29) See Ep. 10 to Gerontius, priest (Easter 432?); ed. by M.-A. CalvetSebasti, P.-L. Gatier (SC, 350), Paris, 1989, pp. 92-93; ep. 35 to Acacius, bishop of Melitene (before 439); ed. by Calvet-Sebasti, Gatier, pp. 150-151.

(30) Ep. 45 to Eugenius, bishop (before 439); ed. by Calvet-Sebasti, Gatier, pp. 172-175.

(31) Ep. 35 to Acacius; ed. by Calvet-Sebasti, Gatier, pp. 150-151.

(32) As demonstrated recently in the case of Theodoret of Cyrrhus by A. M. Schor, Theodoret's People. Social Networks and Religious Conflict in Late Roman Syria (TCH, 48), Berkeley, CA, 2011.

(33) On the genre of the festal letter see P. Allen, "Cyril of Alexandria's Festal Letters. The Politics of Religion," in Studies of Religion and Politics in the Early Christian Centuries, ed. by D. Luckensmeyer, P. Allen (ECS, 13), Strathfield, 2010, pp. 195-210, esp. 196 n. 5. 
called, read aloud in Greek and Coptic in churches and monasteries and studied by monks, were mass media events and, in the hands of a pastor like Cyril of Alexandria (d. 444), a powerful tool: Cyril used his letters to establish his authority as bishop, to attack Jews, pagans, and heretics, and to stop looting and violence perpetrated by rural gangs. ${ }^{34}$ Cyril makes the accusation that iron implements designated for the production of bountiful crops are deployed by farmers to murder their neighbours, and that the resulting crop failure is to be seen as a punishment for these crimes. Almost as a precursor of eco-theology, the bishop fulminates:

How can you then not blush to treat unjustly the things that have given you life's necessities? Down goes your murder victim, and you empurple the earth with innocent blood. How can you still entreat her to become the mother of your crops, when you wrong her so mercilessly? ${ }^{35}$

From Theodoret, bishop of Cyrrhus to the east of Antioch in Syria, we have eight letters dating from 445 and 446 that demonstrate his pastoral involvement with the people of the region who were struggling to pay their taxation to the state in money and kind. ${ }^{36}$ These eight letters were sent to a variety of high-placed addressees belonging to the bishop's network, including the empress Pulcheria, and in them Theodoret pulls out all rhetorical stops, depicting his region and its population in a pitiful light in order to effect a reduction in the tax. He claims (by exaggeration) that the region is mountainous and infertile, addressing two letters to Areobindus, a local landowner. The bishop appeals to Areobindus for mercy on the grounds that, because of crop failure over a period of two years, the farmers of the region are unable to meet their commitment to pay him a tax-in-kind consisting of olive oil.

(34) On Cyril's preoccupation with Jews, pagans and heretics see S. Wessel, Cyril of Alexandria and the Nestorian Controversy. The Making of a Saint and of a Heretic, London and New York, 2004, pp. 39-45. On gang violence see "Cyril's Seventh Festal Letter," in Cyrille d'Alexandrie. Lettres Festales (VII-XI), ed. by P. Évieux et al., vol. 2 (SC, 392), Paris, 1993, p. 42.69-76 (= PG 77, 548A).

(35) Festal Letter 8.3; ed. by Évieux et al., vol. 2, 42, pp. 86-100 (= PG 77, 548A-C); trans. in St. Cyril of Alexandria. Festal Letters 1-12, ed. by P. R. Amidon, with intro. by J. J. O'KeEFe (The Fathers of the Church, 118), Washington, DC, 2009, pp. 144-145.

(36) Letters 42-47, XVII and XX, convincingly dated to 445 and 446 by I. G. Tомкіns, "Problems of Dating and Pertinence in Some Letters of Theodoret of Cyrrhus," Byz, 65 (1995), pp. 176-195 at 184-189, 194. 
...I greet Your Magnificence by letter and beg that the place called Sergitha (it is part of our diocese), which is under your control, may enjoy your kindness. For the amount of oil that the local farmers have to contribute is ruining them, because neither last year nor this has the land produced crops, or extremely little. ${ }^{37}$

In surviving episcopal correspondence from the fifth and sixth centuries, these letters of Theodoret are unique in documenting the pastoral concern of a bishop in the face of the hardship of local farmers and advocating an alleviation of their plight.

Theodoret's ministry also extended to helping refugees from the Vandal invasion of North Africa in 429, many of whom found their way to Syria. First he verified the authenticity of the refugees' stories, observing their behaviour closely, and when convinced that they were genuine, writing letters of recommendation for them. Thus the refugees, and sometimes their families, were introduced to high-placed officials in the church or the state, were given accommodation and protection, and when possible were sent on their way with further letters of recommendation from those to whom they had been introduced by Theodoret. ${ }^{38}$

The bishops of Rome, for their part, used their epistolary networks increasingly to administer their vast estates and to exercise discipline and control in those dioceses at some distance from their city. We detect a degree of micro-managing in the receipts issued by Bishop Gelasius (492-496), for example, in his Letter 32 to the estate manager, Vincomalus:

It is settled that you have put in an amount of thirty solidi of gold to church accounts out of the payment from the farm which you hold on the basis of the farming title, concerning the produce during the year of the consulship of the viri clarissimi Asterius and Praesidius, in the third indiction. I signed on 28 July 495 while the vir clarissimus Flavius was consul. ${ }^{39}$

(37) Ep. XVIII; Correspondance. Théodoret de Cyr, ed. by Y. Azéma (SC, 40), Paris, 1982, p. 90.1-6.

(38) See further B. NeIl, P. Allen, "Displaced Peoples: Reflections from Late Antiquity on a Contemporary Crisis," Pacifica, 24/1 (2011), pp. 29-42.

(39) Epistolae Romanorum Pontificum genuinae et quae ad eos scriptae sunt a S. Hilaro usque ad Pelagium II, ed. by A. Thiel, Braunsberg, 1867; repr. Hildesheim, Zürich and New York, 2004, p. 448; trans. in B. NeIl and P. Allen, Documents from Gelasius I Illustrating the Late-Antique Papacy, Adnotationes, Turnhout, forthcoming. 
If Gelasius had been asked why it was necessary for him, as a carer of souls, to go into such administrative detail, he would have referred to one of his previous directives, which stated that all church income was to be divided four ways: one part to the bishop, one part to the clergy, a third part to the poor, and a fourth for the upkeep of churches.$^{40}$ Thus in a certain sense, by careful financial management of his estates, he was able to ensure the smooth running of the church, including poor relief. On the other hand, it is difficult to see what help to the poor or any other group was given by the micro-managing letter of Bishop Pelagius I of Rome (555-561) to the comes/count Gurdimer in AD 559, telling him that the early growth of trees in the fields along the via Portuensis needs attention, and advising that if Gurdimer does not start to trim them within five or six days, they will drop their seeds and be useless. ${ }^{41}$

Gregory, bishop of Rome from 590-604, was closely involved with the administration of his estates, the most important of which were in Sicily. We have no fewer than 74 of his letters to his administrators on that island, demonstrating his talent for organization and attention to detail. These letters tell us that the administrators were expected to keep a strict account of income and expenditure and provide receipts. ${ }^{42}$ In just one letter to Peter, his administrator, Gregory gives instructions on all the following topics: property disputes involving defrauded nuns, sale of old or sterile cows and oxen, reduction of rents to be paid by converted Jews to encourage further converts, removal of bronze objects belonging to the church, management of hotels, recruitment of staff, construction of a monastery, the need for cooperation with local bishops and imperial officials, the execution of a will of a deceased woman involving the bequest of silver objects, financial administration of a poorhouse, the provision of suitable horses for Gregory's entourage, an annual handout of wine and gold coins to an ex-governor who has fallen on hard times, and the gift of a manuscript to a monastery. ${ }^{43}$

(40) Ep. 14.27; ed. Thiel, p. 378.

(41) Ep. 76; Pelagii I Papae epistulae quae supersunt (556-561), ed. by P. M. Gassó, C. M. Batlle (Scripta et Documenta, 8), Montserrat, 1956, p. 191.

(42) See ep. 13.35; S. Gregorii Magni Registrum epistularum Libri I-VII, ed. by D. Norberg (CCSL, 140 A) Turnhout, 1982, pp. 1037-1039. Trans. by J. R.C. MARTYN, The Letters of Gregory the Great, vol.3, Toronto, 2004, pp. 851-852.

(43) Ep.2.50; ed. Norberg (CCSL, 140), pp. 141-145. See the comments of Martyn, The Letters of Gregory the Great, vol.1, p. 93, and his trans. at pp. 229-236. 


\section{Practical Theology}

The topics of an everyday nature pertaining to Christian living were usually contained in the ethicon and were wide-ranging. We find ethical advice, for example, on usury, church attendance (Chrysostom denounces those who go to church, engage in loud behaviour and gossip, or conduct business deals ${ }^{44}$ ), the importance of having the right intention, dressing in an appropriate manner, correct funeral practices, and respect for clergy.

One of the pastoral concerns many ministers had was how to deal with "heretics". Part of the problem was dealing with the perceived risk of contamination and deciding who were deserving recipients of almsgiving. In the preaching of Bishop Leo of Rome (440-461) we find a preoccupation with the heresies of his day: Manichaeism, Eutychianism, Pelagianism, and Nestorianism. In particular he demonstrates how worried he is about the Manichees, who came to Rome in large numbers after the Vandal invasions in North Africa in 429: the followers of Mani, while claiming to be Christians, refused to accept the birth of Jesus in the flesh, Christ's suffering and crucifixion, and his physical resurrection after death. In addition, they rejected the eucharistic sacrament of the cup, fasted on Sundays and Mondays instead of Wednesdays and Fridays, and considered private property a sin. Hence Leo considered them dangerous enemies of the truth and a real threat to the church in Rome. In 433 he set up a tribunal to investigate and condemn Manichaeism, a court that was composed of secular and ecclesiastical officials and presided over by Leo himself. The condemnation of the heresy that he engineered was corroborated by an imperial edict two years later, outlawing Manichees and laying down severe penalties if any of them were discovered. In this way Leo's ministry extended far beyond the denunciations of the heresy that he proclaimed in his preaching in church. ${ }^{45}$

To both Bishops Gelasius and Hormisdas (514-523) of Rome are attributed works explaining to their flocks what books they were al-

(44) De baptism Christi (CPG 4335); PG 49, 369-372.

(45) B. NeIL, Leo the Great (ECF), London and New York, 2009, pp. 31-33, and B. NeIL, "A Crisis of Orthodoxy: Leo I's Fight against the 'Deadly Disease' of Heresy," in Ancient Jewish and Christian Texts as Crisis Management Literature. Thematic Studies from the Centre for Early Christian Studies, ed. by D. C. Sim, P. Allen (Library of New Testament Studies, 445), London and New York, 2012, pp. $144-158$ at $148-151$. 
lowed to read and what was forbidden. Gelasius states that the compositions of unknown or heretical authors should not be read by the faithful; however, he continues, an anonymous work describing the exploits of Bishop Silvester of Rome (314-335) is read by many in Rome and also in other churches, according to ancient usage, while recent anonymous compositions about the finding of the Lord's cross and the head of John the Baptist are also read at home by Roman Christians. Without actually criticising these practices, Gelasius recommends applying Paul's advice in such cases: "Test everything, hold fast to what is good" (1 Thess 5:21). ${ }^{46}$

The question of ethical behaviour with regard to animals did not escape our pastors either. ${ }^{47}$ In a homily delivered on 28 May 515 on the feast of the Ascension, Severus, patriarch of Antioch (512-518) dwells on the fact that Christ's return to heaven also assures his followers of being seated with him there. In conflict with their privileged seating arrangements in the future, the great gift of divine adoption and participation in a second creation and the first-fruits which have ascended to heaven, Severus' listeners go to the stadium to see fellow-human beings torn to shreds by wild beasts. The sinfulness of the congregation brings tears to his eyes: human beings were given authority over all the animals on earth and the animals were subject to them, thanks to their familiarity with Adam in Eden, such that the bear and the wolf became peaceful creatures. Now, however, because of their fall into sin, human beings no longer have the pure mark of the divine; they fear animals and treat them like savage beasts, who escape from them to deserted places. Those Christians in Antioch who attend the spectacles are contrasted unfavourably with Daniel, Thecla, and other martyrs, who were either in command of wild beasts or used them for their salvation. The sins of the congregation are portrayed by the preacher as having disrupted the natural harmony between human beings and the animal world. ${ }^{48}$

(46) Ep. 42.4; ed. by ThieL, pp. 454-471 at 458-460.

(47) On animal welfare in antiquity see R. Sorabj, Animal Minds and Human Morals: The Origins of the Western Debate, London, 1993, pp. 195-205.

(48) Hom. 26; ed. and trans. by M. Brière, F. Graffin (PO, 36/4), Turnhout, 1974, p. 548, and hom. 54; ed. by R. Duval (PO, 4/1), Paris, 1906, p. 49. See P. Allen, "Severus of Antioch as Theologian, Dogmatician, Pastor, and Hymnographer," Questions liturgiques, 92 (2011), pp. 359-373. 


\section{Episcopal Crisis Management as a Strategy of Ministry ${ }^{49}$}

In his short bishopric of about eighteen months Bishop Synesius of Cyrene in North Africa was faced with various crises, both private and public: the death of his last remaining child, ${ }^{50}$ barbarian incursions which forced him to join the citizens of his town on the ramparts "several times a month," 51 and a crisis of conscience and consequent depression about whether he should be a bishop at all..$^{52}$ However, Synesius' dispute between February and March 412 with the civil governor of Pentapolis, Andronicus, is one of the highlights of the bishop's correspondence, comprising about one-eighth of the total number of his surviving letters. The dispute is a remarkable example of both public and private crisis management, in that Andronicus was a cruel and rapacious official against whom, until the dénouement of the crisis, Synesius as bishop appeared ineffectual and depressed. The governor, a parvenu as Synesius likes to point out, was known for his panoply of sophisticated instruments of torture and his merciless extortion of gold from members of the curial or senatorial class. Andronicus is depicted by Synesius as the latest in a list of disasters to have befallen Pentapolis, from the earthquake of 365 over forty years earlier, to the recent plagues of grasshoppers, famine and fires of the year 411, and the raids of the Berber Ausurians in the same year. ${ }^{53}$ When Synesius visited a well-born citizen who was being tortured while incarcerated,

(49) On this topic see in detail P. Allen, B. NeIl, Crisis Management in Late Antiquity (410-590 CE) (VC Supp.), Leiden, forthcoming. For a more detailed treatment of crises dealt with by Synesius and Augustine see P. Allen, "Brushes with the Imperium: Letters of Synesius of Cyrene and Augustine of Hippo on Crisis," Basileia: Essays on Imperium and Culture in Honour of E. M. and M. J. Jeffreys, ed. by G. Nathan, L. Garland (Byzantina Australiensia, 17), Brisbane, 2011, pp. 45-53.

(50) Ep. 89; ed. and trans. by A. Garzya, D. Rouues, Synésios de Cyrène. Correspondance, vol. 3, Paris, 2000, p. 211.6-7.

(51) Ep. 89; ed. by Garzya, Roques, vol. 3, p. 211, 4. Cf. epp. 69, 73, and 94.

(52) See epp. 11, 13, 41, 96, and 105.

(53) Ep. 42; ed. by Garzya, Rouues, vol. 2, p. 70.9. For treatments of the Synesius-Andronicus affair see e.g. R. Lizzi, "Il potere episcopale nell'oriente romano. Rappresentazione ideological e realtà politica (IV-V sec. d. C)," Filologia e Critica, 53 (1987), pp. 85-111; D. Roques, Synésios de Cyrène et la Cyrènaïque du bas-empire (Études d'antiquités africaines), Paris, 1987, pp. 366-370. Further bibliography is in Allen, "Brushes with the Imperium," esp. p. 46 n. 6 and p. 49 n. 28. 
Andronicus was infuriated and, we are told, repeatedly blasphemed against Christ. ${ }^{54}$ The inhabitants of the town looked to Synesius for help, not so much, it seems, because of his episcopal office as because of his standing as curialis in his native region. However, the bishop felt himself powerless, and, overcome also by the recent death of his oldest son and last remaining child, remained impervious to the consolations of philosophy and of prayer. ${ }^{55}$ In his depressed state he was even tempted to leave the episcopal office. ${ }^{56}$ It needs to be remarked that our evidence of the conflict between official and bishop is on (Pe-sided in that we rely totally on Synesius' account, the main aim of which is to demonise his opponent. ${ }^{57}$ What is significant in the crisis precipitated by the conduct of Andronicus is that neither bishop nor citizens appealed to the law. Instead Synesius pronounced an edict of excommunication on the governor which was sent to all bishops in the region and was meant to extend to all churches in the Christian world (ep. 41). Far from repenting, Andronicus subsequently confiscated and sold public property, and committed murder. The sentence of excommunication was then ratified, banning Andronicus from churches and communion everywhere, and stating that Christians would refuse to shake his hand or sit at table with him. While sentences of excommunication were not new in this period, the fate imposed on Andronicus was harsh because the excommunicate should have had the possibility of doing penance and/or seeking asylum. Synesius also effectively denied Andronicus the right of asylum, and there was consequently no option for the official but to leave town and his job. In a stroke of administrative genius, albeit one that could not be considered civilly legal, the pastor had succeeded in ridding himself and his people of a crisis of considerable proportions.

Conflict and violence are documented in Letters 91 and 104 of Augustine to Nectarius, an official of Calama, a small town in the hinterland of Hippo Regius whose bishop, Possidius, subsequently became Augustine's biographer. ${ }^{58}$ In Letter 91, written in 408 or 409, Augustine

(54) Ep. 42; ed. by Garzya, Roques, vol. 2, p. 56.50-54.

(55) Ep. 41; ed. by Garzya, Roques, vol. 2, p. 47.200-201.

(56) Ep. 41, ed. by Garzya, Roques, vol. 2, p. 43.86-89 and p. 53. 363-367.

(57) See further Lizzi, Il potere, p. 105.

(58) NBA, 21/2, Rome, 1992, pp. 782-795 and 1000-1021, respectively; trans. by R. Teske, (WSA, 2/1), Hyde Park, NY, 2001, pp. 365-374 and (WSA, 2/2), Hyde Park, NY, 2003, pp. 43-53. On the episode see E. T. Hermanowicz, 
related that on 1 June 408 a group of "pagans", walking and dancing in procession and possibly carrying a statue of a pagan god, approached Possidius' basilica. When intercepted by the clergy, they began throwing stones at the church. It was only after a week that the bishop went to the secular officials demanding protection and recompense on the basis of the laws which prohibited the celebration of pagan festivals. The church, however, was stoned on another two occasions, then set ablaze. As the bishop and clergy went into hiding, the crowd looted property and some Christians were killed. As senior bishop Augustine went to Calama to help Possidius vindicate his case against the town's magistrates, but his intervention was fruitless and the bishop of Calama took his grievances to the court in Ravenna. It is not clear who these "pagans" were, perhaps townspeople who wanted to assert more aggressively their right to celebrate the annual summer festival of 1 June, but in any case their actions were seen as provocative by the clergy. Neither the local bishop, Possidius, nor Augustine himself was successful in managing this crisis.

Sidonius Apollinaris was appointed bishop of Clermont-Ferrand between 469 and 472 partly to defend the area from the crisis of the Visigoth invasion. His letters contain many references to the devastation wrought by the intruders: buildings and houses outside Clermont have been damaged or destroyed; armed bands are terrorising the inhabitants; and church buildings have fallen into disrepair. ${ }^{59}$ Sidonius, writing to Bishop Mamertus of Vienne after the siege of Clermont-Ferrand by the Visigoths in 473 , speaks of "hideously charred walls", "palisades of rotting stakes", and "battlements worn by the beasts of many a sentinel", adding "our only comfort is in the aid of the Rogations which we introduced on your advice ... and it because of these rogations that they [the people of Clermont] are not yet retreating from the terrors that encircle them." ${ }^{60}$ In another letter, which can be dated to early $473 \mathrm{CE}$, the bishop again mentions Rogations, which were performed

Possidius of Calama. A Study of the North African Episcopate at the Time of Augustine, Oxford, 2008.

(59) On Sidonius' life, letters, and times see J. Harries, Sidonius Apollinaris and the Fall of Rome, A.D. 407-485, Oxford, 1994.

(60) Ep. 7.1; ed. and trans. by W. B. Anderson, Sidonius, Letters III-IX (LCL, 420), Cambridge, Mass and London, 1965, repr. 1997, pp. 287-288. On Book 7 of Sidonius' letters see now J. A. van WaArden, Writing to Survive. A Commentary on Sidonius Apollinaris. Letters Book 7, vol. 1: The Episcopal Letters 1-11 (Late Antique History and Religion, 2), Leuven, 2010, pp. 69-126. 
at Clermont during irruptions and siege by Visigoths. The depth of the crisis posed by the Visigoths in Gaul can be ascertained by the fact that Sidonius himself was forced to flee before them in 476-477. However, it is the role of the spectacular Rogation ceremonies in Sidonius' stage-managing of the Visigothic crisis that I would like to concentrate on here. The Rogations were ceremonies usually of three days' duration during which every inhabitant of the affected area was expected to take part. ${ }^{61}$ Fasting, prayer, abstinence (also from work), and almsgiving were obligatory, while vigils and processions were organised. The communal crisis facing the townspeople, which was regarded as a punishment for collective or individual sin, could only be averted by communal participation. In these visually impressive ceremonies bishops like Sidonius played a vital role because usually they commemorated the forgiveness of sin through Christ's death which was seen as a promise of release from disaster, in this case the crisis posed by war against the barbarians. Yet it must be said that the sin-punishment syndrome as an explanation of crisis is not evident in Sidonius' letters, for he exonerates himself with the comment that "we ourselves are being visited with glaring penalties for obscure offences." ${ }^{\prime 2}$

During the years 494-506 Edessa in Syria witnessed not only plague but also earthquakes, infestations of locusts, solar phenomena, and famine. The chronicler Ps.-Joshua the Stylite gives a detailed description of the plague that hit his city, including the following lines.

As all the people had sinned, they all fell victim to this disease. Swellings and tumours appeared on all our citizens, and the faces of many became puffed up and filled with pus, making it a fearful sight. Some had sores or pustules over their whole body, even to the palms of their hands and the soles of their feet, while others had great fissures on every single limb. ${ }^{63}$

(61) See G. Nathan, "The Rogation Ceremonies in Late Antique Gaul: Creation, Transmission and the Role of the Bishop," Classica et Mediaevalia, 49 (1998), pp. 275-303.

(62) Ep. 3.4; ed. and trans. by Anderson, p. 23. On the sin-punishment syndrome see E. WAtTs, "Interpreting Catastrophe: Disasters in the Works of Pseudo-Joshua the Stylite, Socrates Scholasticus, Philostorgius, and Timothy Aelurus," Journal of Late Antiquity, 2 (2009), pp. 79-98.

(63) Text in J.-B. Снавот, Incerti Auctoris chronicon Pseudo-Dionysianum vulgo dictum 1 (CSCO, 91, Scr. Syr. 43), Paris, 1933, p. 253; trans. by F. R. Trombley, J. W. Watt, The Chronicle of Pseudo-Joshua the Stylite (Translated Texts for Historians, 32), Liverpool, 2000, p. 23. 
In the ensuing mayhem of a quadruple affliction, the citizens took to violence, and the bishop of the city, Cyrus, urged them to make donations towards eucharistic vessels with which to placate the Deity. Cyrus and his successor, Peter, who replaced him in 498, play a prominent role as crisis managers in Ps.-Joshua's narrative. In the wake of the solar phenomena, for example, Bishop Peter is said to have organised processions, public prayers and hymn-singing, and to have petitioned the emperor to waive taxes for the people of Edessa. ${ }^{64}$

One bishop who had more than his fair share of managing crisis was Patriarch Ephrem of Antioch. ${ }^{65}$ At the time of the catastrophic earthquake in the city in 526 Ephrem was comes Orientis, the imperial official in charge of troops in the eastern empire, and subsequently responsible for the reconstruction of the city. This he did so efficiently that he was elected patriarch by a grateful citizenry in 526/7 and remained in that office until his death in 544. During his tenure he rebuilt the city a second time after another earthquake in 528, fled before the Persian invasion in 540, perhaps negotiated with the Persians invaders to save the Great Church, and with his people withstood a serious occurrence of the plague in 542. During his entire patriarchate he was also heavily involved in christological conflict. While in the tenth century Patriarch Photius of Constantinople knew of fourteen of Ephrem's letters, ${ }^{66}$ none of them has survived, but we may surmise that numerous other letters from such a high-profile and active imperial functionary, patriarch, and theologian, some of them perhaps referring to the natural disasters that he managed in the course of his ministry, have also unfortunately perished.

\section{Concluding Remarks}

I hope to have shown that the acts of preaching that occurred within the liturgical context in Christian antiquity were but one aspect of the ministry of the time. While sermons reveal much about the commit-

(64) Ed. by Снавот, pp. 263, 301; trans. by Твомвley, Watt, pp. 35-36, 95.

(65) See the classic biography by J. Leвon, "Éphrem d'Amid, patriarche d'Antioche," in Mélanges d'histoire offerts à Ch. Moeller à l'occasion de son jubilé de professorat à l'Université de Louvain (1863-1913) par l'Association des Anciens Membres du Séminaire Historique de l'Université de Louvain, vol. 1, Université de Louvain (Recueil de travaux publiés par les membres des conférences d'histoire et de philologie, 40), Louvain and Paris, 1914, pp. 197-214.

(66) See the list in CPG 6908. 
ment of the pastor to his flock, his letter-writing and other activities in the social and political life of his community were equally important. The preachers' epistolary networks with influential people were often put at the disposal of their flocks, and the instance of Leo's political manoeuvring in the imperial condemnation of Manichaeism illustrates how powerful a bishop could be in the secular sphere. However, given the wide range of social, religious, ethical, and political issues addressed by preachers and ministers in this period, their attitudes to topics like poverty and riches are perhaps disappointing for modern readers who expect them to champion the poor unreservedly and to be influential advocates for voluntary poverty. Likewise, in the works of these preachers and ministers we find no condemnations of slavery or slave-owning - on the contrary, slavery is seen as part of the status $q u o$, or perhaps as a result of the Fall, or even sometimes as a positive good.

It is very fortunate that recent studies on the increasingly important civic role of bishops in late antiquity ${ }^{67}$ have given us a more comprehensive overview of their entire ministry, because it has been argued that after the sixth century the art of preaching went into a decline. ${ }^{68}$ Even before the end of the sixth century we find preachers being instructed to recycle homilies that had been delivered by earlier homilists. ${ }^{69}$ In addition, there are examples of works other than homilies being read in church, such as the Questions and Answers of the seventhcentury writer, Anastasius of Sinai, who replied in a liturgical context to questions of everyday life posed by the congregation..$^{70}$ We shall

(67) See e.g. the studies of A. STERK, Renouncing the World Yet Leading the Church: The Monk-Bishop in Late Antiquity, Cambridge, Mass. and London, 2004; C. Rapp, Holy Bishops in Late Antiquity. The Nature of Christian Leadership in an Age of Transition (TCH, 37), Berkeley, Los Angeles and London, 2005; ScHor, Theodoret's People.

(68) For the argument see P. Allen, "The Sixth-century Greek Homily: A Re-assessment," in Preacher and Audience, ed. by Cunningham, Allen, pp. 201-225, esp. 201.

(69) Discussed by Bingham, The Antiquities of the Christian Church, Book XIV, ch. IV.22, pp. 587-589.

(70) Text in M. Richard and J. A. Munitiz, Anastasii Sinitae Quaestiones et Responsiones (CCSG, 59), Turnhout, 2006; trans. by J. A. Munitiz, Anastasius of Sinai. Questions and Answers (Corpus Christianorum in Translation, 7), Turnhout, 2011; cf. J. HALdon, "The Works of Anastasios of Sinai: A Key Source for the History of East Mediterranean Society and Belief," in The Early Medieval 
nevertheless not be wrong in thinking that even under these changed circumstances, the general ministry to the faithful outside the church building continued in the ways I have outlined: care of the poor, administration of the church through letter-writing, prevention of violence, and working for unity of the Christian community.

\section{SUMMARY}

In this article I shall investigate the track-records of a number of Greek- and Latin-speaking preachers and ministers during the period AD 400-600. A sample of these includes John Chrysostom (Antioch and Constantinople), Augustine of Hippo (North Africa), Synesius of Cyrene (North Africa), Firmus of Caesarea in Cappadocia, Theodoret of Cyrrhus in Syria, Sidonius Apollinaris of Clermont-Ferrand, Gelasius of Rome, Severus of Antioch, and Gregory I of Rome. As well as their involvement in preaching and liturgy, I shall investigate their activities outside the church building, such as their letter-writing networks and political involvement. Aspects of practical theology will also be addressed, for example, their approach to church attendance, fasting and almsgiving, voluntary poverty, and ethics in general. In conclusion I shall consider the pastoral role of the late-antique bishop as a manager of crisis.

East: Problems in the Literary Source Materials, ed. by A. Cameron, L. Conrad (Studies in Late Antiquity and Early Islam, 1), Princeton, NJ, 1992, pp. 107-147. 